
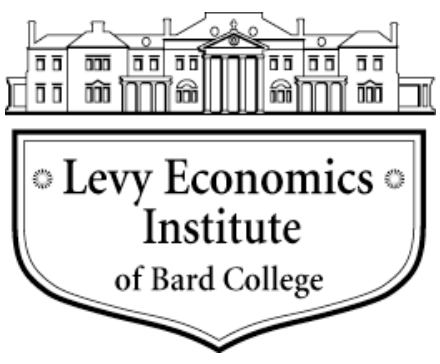

Working Paper No. 838

\title{
Unpaid Work and the Economy: Linkages and Their Implications*
}

by

\author{
Indira Hirway ${ }^{\dagger}$ \\ Levy Economics Institute of Bard College
}

May 2015

\footnotetext{
* This paper is adapted from Indira Hirway's presidential address at the 56th Annual Conference of the Indian Society of Labour Economics in December 2014. The author is thankful to Rania Antonopoulos and Reiko Tsushima for their useful comments.

† indira.hirway@cfda.ac.in
}

The Levy Economics Institute Working Paper Collection presents research in progress by Levy Institute scholars and conference participants. The purpose of the series is to disseminate ideas to and elicit comments from academics and professionals.

Levy Economics Institute of Bard College, founded in 1986, is a nonprofit, nonpartisan, independently funded research organization devoted to public service. Through scholarship and economic research it generates viable, effective public policy responses to important economic problems that profoundly affect the quality of life in the United States and abroad.

\author{
Levy Economics Institute \\ P.O. Box 5000 \\ Annandale-on-Hudson, NY 12504-5000 \\ http://www.levyinstitute.org
}

Copyright (C) Levy Economics Institute 2015 All rights reserved

ISSN 1547-366X 


\begin{abstract}
Unpaid work, which falls outside of the national income accounts but within the general production boundary, is viewed as either "care" or as "work" by experts. This work is almost always unequally distributed between men and women, and if one includes both paid and unpaid work, women carry much more of the burden of work than men. This unequal distribution of work is unjust, and it implies a violation of the basic human rights of women. The grounds on which it is excluded from the boundary of national income accounts do not seem to be logical or valid. This paper argues that the exclusion reflects the dominance of patriarchal values and brings male bias into macroeconomics.

This paper shows that there are multiple linkages between unpaid work and the conventional macroeconomy, and this makes it necessary to expand the boundary of conventional macroeconomics so as to incorporate unpaid work. The paper presents the two approaches: the valuation of unpaid work into satellite accounts, and the adoption of the triple "R" approach of recognition, reduction, and reorganization of unpaid work, recommended by experts. However, there is a need to go beyond these approaches to integrate unpaid work into macroeconomics and macroeconomic policies. Though some empirical work has been done in terms of integrating unpaid work into macro policies (for example, understanding the impacts of macroeconomic policy on paid and unpaid work), some sound theoretical work is needed on the dynamics of the linkages between paid and unpaid work, and how these dynamics change over time and space. The paper concludes that the time has come to recognize that unless unpaid work is included in macroeconomic analyses, they will remain partial and wrong. The time has also come to incorporate unpaid work into labor market analyses, and in the design of realistic labor and employment policies.
\end{abstract}

Keywords: Unpaid Work; System of National Accounts; Time-Use Survey; Gender Equality

JEL Classifications: D13, E01, I3, J3, J08, J16 


\section{INTRODUCTION}

Unpaid work is essentially that work which does not receive direct remuneration. It includes unpaid work that falls within the production boundary of the System of National Accounts $(\mathrm{SNA})^{1}$ and unpaid work that falls outside the production boundary (non-SNA). ${ }^{2}$ The former unpaid work, which is a part of the conventional economy and is expected to be covered under the national income accounts, includes three types of work: (1) unpaid family work in family enterprises; (2) the production of subsistence goods by households for own consumption, and the free collection of products, also for own consumption (such as water, fuel-wood, fish, fruit, etc.); and (3) the collection of free goods for production purposes (such as fodder, wood, craft material, etc.). The latter work (i.e., unpaid non-SNA work), on which $35 \%$ to $50 \%$ of total work time is spent by economies (Antonopoulos 2009, Hirway and Jose 2011), includes daily activities for household upkeep (e.g., cooking, washing, cleaning, shopping for own household, etc.), care work (e.g., care of children, the old, the sick, disabled and others that need care), and unpaid voluntary services. Unpaid SNA work, which is covered under the national income accounts, is expected to be visible in national statistical systems, ${ }^{3}$ while unpaid non-SNA work, which is outside the national income accounts, is usually invisible in national statistical systems. This paper focuses on unpaid non-SNA work, although unpaid SNA work is referenced when required.

It is important to note at the outset that according to the SNA document (UN 2008), the five sectors that constitute the total economy are: (1) non-financial corporations, (2) financial corporations, (3) the government sector including social security funds, (4) non-profit institutions serving households (NPISH), and (5) the household (UN 2008). The production boundary (SNA) includes all of the production of goods and services for sale or barter, and the goods and services provided free to households or collectively to the community by government units or NPISH. In addition, it also includes the following non-market production:

\footnotetext{
${ }^{1}$ The System of National Accounts (SNA) is the internationally agreed-upon standard set of recommendations on how to compile measures of economic activity in accordance with strict accounting conventions based on economic principles (UN 2008). This document defines the "production boundary," which determines what goods and services must be included in national income accounts. This boundary is also known as the boundary of SNA. ${ }^{2}$ Non-SNA work is defined as all work carried out outside the production boundary that can be delegated to others. ${ }^{3}$ National income estimates frequently do not follow the production boundary due to methodological problems or due to the lack of required data.
} 
- the production of agricultural goods by household enterprises for own use;

- the production of other goods for own final consumption by households (e.g., the construction of dwellings, the production of food stuff, clothing, etc.); and

- the production of housing services for own final consumption by owner-occupiers (imputed rent).

What is excluded from the production boundary is the production of services for own final consumption within households (excluding the services of paid domestic staff) and voluntary unpaid services. This is non-SNA work, and it is excluded from the national income accounts.

\section{Unpaid (Non-SNA) Work as "Care"}

Unpaid (non-SNA) work (hereafter "unpaid work") is viewed variously by different scholars. Several scholars view it as unpaid care (i.e., a constituent part of the care economy). "Care" can be defined as meeting the physical and emotional requirements of dependent adults, children, and others. According to Nancy Folbre, care is "the work that involves connecting to other people, to help people meet their needs" (Folbre 1995). It is an intrinsic goal of development, as it is essential for maintaining daily life and human reproduction.

It is a basic duty of the state as part of the social contract to see that care is provided to all who need it. Care is usually provided by four institutions: households, governments, markets, and voluntary organizations. These "care diamond" institutions are expected to organize care in such a way that adequate and good quality care is reliably available to all who need it; however, if there are any gaps, the government is expected to fill in the gaps (Budlender 2010).

"Unpaid" care refers to the unremunerated care provided to own household members, relatives, and the community. The United Nations Research Institute for Social Development (UNRISD) has divided unpaid care into direct care (mainly physical care and teaching children, etc.) and indirect care (minding children, accompanying them to places, etc.). Indirect care also includes household upkeep. The unpaid care provided by households is the most important part of care, as it keeps families together and nurtures human and social values. Even with economic development, the time devoted to unpaid work does not decline, as shown by empirical studies 
(Folbre and Yoon 2008) ${ }^{4}$. Unpaid care services play an important role, particularly in countries where basic infrastructure and public services are weak, in removing what Amartya Sen calls "un-freedoms."

\section{Unpaid Work as "Work"}

Many other scholars emphasize that unpaid work is work that uses the time and energy of household members to produce goods (such as meals, snacks, etc.) and services to increase the well-being of households. At the macro level, this work improves the overall performance of the economy. Unpaid work is a productive use of human labor, and it contributes to human capital formation by raising and nurturing children. It also takes care of the depreciation of labor and enables people to go back to work the next day. ${ }^{5}$ Unpaid work is therefore an important component of the economy.

As seen above, the SNA also considers non-SNA work to be part of "economic work." The $19^{\text {th }}$ International Conference of Labour Statisticians (ICLS) Resolution on "Statistics on Work, Employment and Labour Underutilization" also includes unpaid non-SNA work as a part of “work." This resolution defines work as "any activity performed by persons of any age and sex to produce goods and services for use of others or own use except for non-delegable personal services" (International Labour Organization 2013).

Both the above approaches to unpaid work (i.e., defining it as "care" and as "work," are important for the economy as, according to both of these approaches, unpaid work contributes to the total output and well-being of the economy.

\section{Specific Concerns about Unpaid Work}

There are several reasons why unpaid work is an important area of concern for an economy, and why one should pay attention to this work. To start with, the distribution of unpaid work between men and women (also between rich and poor) is highly unequal. Time-use surveys, though not universal, national, or regular in many countries, clearly indicate: (1) unpaid work is

\footnotetext{
${ }^{4}$ This study of 15 European countries by Folbre and Yoon shows that athough the time spent on household upkeep declined overtime, the total time spent on non-SNA activities did not decline in the long run because time spent on care - child care and other care - increased in the long run. As a result, one does not find any decline in the time spent on non-SNA activities in the long run, though the time spent on household upkeep declined to an extent. ${ }^{5}$ When a worker goes back in the evening, he needs food, clean clothes, clean home, etc., so that he can get rejuvenated and is able to go back to work the next day. Unpaid work thus addresses the wear and tear on labor, i.e. depreciation of labor.
} 
highly unequal in its distribution between men and women, with women shouldering the main burden, in terms of participation as well as the time spent on unpaid work, ${ }^{6}$ (2) paid work is also distributed unequally with men carrying a somewhat higher burden, and (3) women carry a significantly higher burden of total work (paid and unpaid work) than men (Hirway 2010, Antonopoulos 2009, Charmes 2005. This extremely unequal distribution of work is an area of concern not only for gender justice but also for the economy, as discussed below.

Another reason why unpaid work deserves the attention of scholars is that unpaid work has several built-in weaknesses. Unpaid work is mostly invisible, as time-use data have not become a regular feature of national statistical systems in many countries as of yet, particularly in the Global South. ${ }^{7}$ Even when some time-use data are available, this unremunerated work is not yet recognized as important work that should be covered under economic policies. In addition, unpaid work is repetitive (i.e., performed daily), boring, and frequently a drudgery. ${ }^{8}$ Unpaid workers do not enjoy any upward mobility or promotions, and therefore these are deadend jobs. There is no retirement or pension connected to this type of work. Unpaid workers also have limited exposure to the outside world and limited opportunities in life. This implies that a significant part of the total labor force in a given economy is locked into a low-productivity, inferior kind of work.

Unpaid work is also seen as "household overhead time" (HOT), which is defined as the minimum number of hours a household needs to maintain and manage itself (i.e., the minimum number of hours needed to transform raw materials to consumable goods and to provide a clean and healthy environment (Harvey and Taylor 2000). In poor countries, and particularly in poor households, where more time is needed to process food, cook, clean, and so forth, and to fetch water and fuel wood (due to poor availability of basic infrastructure), the HOT is very high. Therefore, in poor countries and poor households, very limited time is left for resting, for acquiring human capital — education, skills_ — or for productive labor market work (Blackden and Wodon 2006 and Hirway 2010). In cases where a household's children are involved in this

\footnotetext{
${ }^{6}$ Time use data show that women spend 40-500 \% more time on non-SNA unpaid work (Hirway 2005, Antonopoulos 2009)

${ }^{7}$ In all, about 40-60\% of the countries in the global south have conducted at least one time use survey. Of these, less than $3 \%$ of countries have mainstreamed time use surveys in their national statistical systems.

${ }^{8}$ The drudgery part of work includes that work which is strenuous and time consuming. For example, women in most developing countries in Africa, Asia, and Latin America spend considerable time fetching water, collecting fuel wood, collecting fodder and other free goods, or on petty urban work.
} 
work, as is usually found in poor households, the future generation will also have to pay the cost of high HOT.

What is important to note is that the predominance of women in this work is not a result of their free choice or their relative efficiency or inefficiency. The division of work between men and women is largely a social construct - determined by patriarchal traditions and values. In fact, this highly unequal distribution is at the root of power relations between men and women, and all pervasive gender inequalities.

As this work falls outside the scope of economic policies, the drudgery of the work, along with the time stress of unpaid workers, the technology and the productivity of this work, the working conditions, and so on, are also outside the purview of policymaking. Thus unpaid work that contributes significantly to the economy is not addressed systematically in policymaking.

\section{The Division of SNA-Non-SNA is Arbitrary}

A careful look at the literature on the SNA shows that several non-market activities have been added to the SNA boundary over time (UN 1993, 2008). ${ }^{9}$ Though both SNA and non-SNA activities are considered as "economic activities," the demarcation line is fixed arbitrarily as a "compromise." While the unpaid production of goods for household's own final consumption is included within the production boundary, the unpaid production of services for household's own final consumption is left out of the production boundary. This is because, as the document points out, the decision as to whether goods are to be sold or retained can be made even after they have been produced (UN 2008). This argument is not satisfactory because unpaid services also move in and out of the market depending on different micro- or macro-level situations. ${ }^{10}$

It is argued that unpaid services are excluded from the production boundary because: (1) non-monetary flows have little relevance for macroeconomics, (2) inclusion of unpaid work will overwhelm national accounts, and (3) inclusion will imply a full employment condition, which does not make much sense (UN 2008). These arguments do not appear to be valid for several reasons. First, non-SNA or non-monetary flows have strong linkages with market flows. In fact, as we will soon explain, macroeconomic forces have a significant influence on the size and

\footnotetext{
${ }^{9}$ As seen above, additions of non-market work to the SNA boundary include production of goods for selfconsumption, subsistence agriculture, self-consumption of own dwelling, etc.

${ }^{10}$ This is explained later in this paper.
} 
characteristics of non-SNA. Second, unpaid work is significant and therefore cannot be excluded from the total economy, irrespective of the fact that it does or does not overwhelm the national accounts. Third, the inclusion of unpaid work requires the modification of certain concepts (such as workforce and labor force) and new analytical tools, not the exclusion of unpaid work from the SNA boundary.

Luisella Goldschmidt-Clermont, an eminent economist, who worked with the International Labour Organization (ILO) for many years, finds this demarcation line between SNA and non-SNA highly illogical. She argues that the production process continues in both market and non-market spheres. For example in food production, there is the sequence of crop farming - harvesting - processing - storing - processing - cooking - consumption. Except for the last stage, all of the processes are production, value addition, and all should be included in the SNA. Similarly, human capital formation starts with nurturing a child (by taking care of its health and education, etc.) at home and continues thereafter in schools. However, human capital formation is recognized only after the child goes to school. Goldschmidt-Clermont calls this demarcation line a "patriarchal line," not justifiable on any grounds (Goldschmidt-Clermont 1987 and 1989). This patriarchal demarcation line puts non-SNA under a shroud of invisibility and puts it outside the purview of economic policy: in the process it adds a male bias in macroeconomics. In other words, this division forces policymakers to adopt a partial and biased view of the economy.

\section{The Division Implies Violation of Gender Justice and the Human Rights of Women}

The above discussion shows that non-SNA work is a kind of time tax on women throughout their life cycle. This time tax tends to reduce the time available for remunerative work, leisure time, and time for the education and health of women. In the case of poorer groups, this time tax tends to trap the poor and particularly poor women in poverty-in both income and time poverty $^{11}$ (Hirway 2010). As Rania Antonopoulos puts it, this is a form of social and economic exclusion of women from the market and from the mainstream economy. It is a de facto segregation of women in the economy (Antonopoulos 2009).

\footnotetext{
${ }^{11}$ Hirway's study has shown that due to the time stress caused by paid and unpaid work, poor and particularly poor women do not have much time left for education/skill training, self-improvement, social networking, or even rest. As a result, there is a limited scope for them to get out of the trap of poverty (Hirway 2010).
} 
This can also be viewed as a violation of the basic human rights of women. The lopsided distribution of paid and unpaid work between men and women violates women's right to equal opportunities, as well as their right to non-discrimination, right to education and health, and right to work. It also violates their right to social security as unpaid workers, right to enjoy the benefits of scientific progress, and the right to participation. The report of the Special Rapporteur on Extreme Poverty and Human Rights points out, for women of the extremely poor households, this unequal distribution results in violation of basic social, cultural, economic, and political rights (UN 2013).

\section{Unpaid Work and Poverty}

It can be observed that in official poverty calculations the links between unpaid work and living standards have been largely ignored. This omission would not be troublesome if the time necessary to engage in such production were always readily available. But this is not necessarily the case. Frequently, the household upkeep time is high and households do not have the income resources or state-provided services to meet their needs for care services. Official poverty estimates do not capture the full extent of this deprivation. Further, it is quite plausible that the joint distribution of time and income deficits differs systematically across population subgroups (e.g., income distribution, large-size families with children, urban versus rural place of residence, formally employed versus own account workers, etc.). Should this prove to be the case, the reported data on the incidence and depth of poverty are inaccurate. It also follows that poverty trends can be biased, and hence highly misleading. If we accept the proposition that household production contributes to a household's standard of living, taking time deficits into account makes for better measurement of income and consumption poverty. Tracking both can reveal vulnerabilities that have, so far, remained hidden — while all along they have been affecting, in distinct ways, different segments of the population. Such alternative measures do exist and a good example can be found in a recent United Nations Development Programme (UNDP) publication focusing on three Latin American countries (Antonopoulos et al. 2012). ${ }^{12}$

\footnotetext{
${ }^{12}$ Antonopoulos et al. 2012. The Interlocking of Time and Income Deficits: Revisiting Poverty Measurement, Informing Policy Responses. UNDP, Regional Service Centre for Latin America and the Caribbean, Panama.
} 
This alternative measure reveals that a much wider segment of the population is falling below minimum thresholds of living standards (i.e., these segments are worse off than officially estimated). The conventional measures may prove to be inadequate here. That is, poverty reduction interventions for specific pockets of the population require well-coordinated and not isolated, one-off, interventions. Policies must be simultaneously rolled out so that inequalities in paid work (related to labor markets and employment) and unpaid work are addressed coherently. This type of methodology that puts time use surveys to good use must gain more visibility and become a standard practice among statistical agencies.

\section{Unpaid Work and the Macroeconomy}

\section{Unpaid Work in Economic Theories}

Economic theories in the past failed to recognize unpaid work as a part of the mainstream economy. Classical economists stated that unpaid domestic services were not production, because "production is only in the market." An unpaid service within a home is the consumption of the incomes earned. Neo-classical economists considered unpaid work within households as outside the purview of economics, also because unpaid work is non-market work-the labor of dependents and not the labor of breadwinners. Market work is only the work of the breadwinner. Also, unpaid work is not an economic good, because it is "free" and is "unlimited."

Simon Kuznets, the father of national income accounts, who compiled national income accounts for the first time (for the United States), also kept unpaid work outside the purview of national income, as it is "housewives' production" and is therefore not a part of the economy.

The above arguments for excluding unpaid work from mainstream economic theories are not acceptable to some of the present-generation economists who approach macroeconomics realistically and logically. It is to be accepted that domestic unpaid services are not just consumption, but also represent production by household members. Also, unpaid work is not free (it has a cost). It is also not unlimited (there are limits on women's capacity to work), and therefore, it is an economic good. 


\section{Household as a Production Unit}

Chart 1 (below) shows how the household is one of the three sectors of the macroeconomy. It is not an add-on sector or an afterthought; it is a fundamental building block, structurally interlinked with the other two sectors, namely the public sector and the market.

The chart also shows that the household sector provides formal labor, informal labor, and unpaid labor to the economy. This labor is provided to the business sector and the public sector. Both these sectors get formal and informal labor from the household sector. The household sector also provides formal paid work and voluntary work to nonprofit institutions. Similarly, the business sector and the public sector provide goods and services to the household sector and to nonprofit institutions. The business sector also provides goods and services to the public sector. Finally, the public sector also provides services to the business sector, the household sector, and to nonprofit institutions. This chart depicts very clearly the linkages between the three fundamental sectors in the macroeconomy.

The chart implies that how people divide their time between paid (SNA) and unpaid work (non-SNA) ought to be used to understand the impact of macro policies on those performing paid work, as well as those performing unpaid work (Antonopoulos 2009).

\section{Chart 1}

Business Sector: agriculture, industry and services

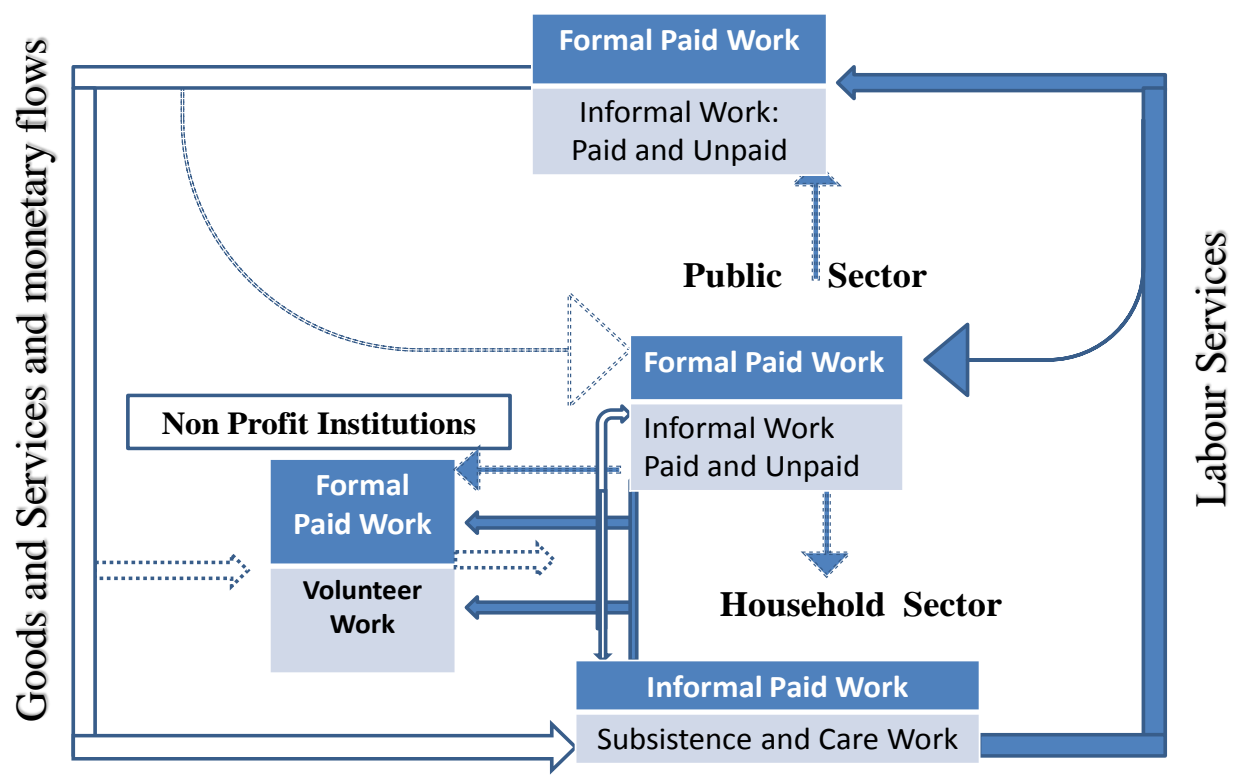

Source: Diane Elson (2008). 


\section{Unpaid Work as Subsidy to the Macro-economy}

The relationship between the non-SNA sector and the rest of the economy indicates that the latter subsidizes the macroeconomy in multiple ways (Antonopoulos and Hirway 2010). Households (unpaid work) provide several services that the government is expected to provide to people. These include care and basic public provisioning. Households take care of sick and chronically sick people, as well as disabled and elderly people, and provide education, health, and nutrition to children. Voluntary unpaid services also provide those services to people for which the state is supposed to be responsible. All these unpaid services therefore tend to reduce the burden on the state. In the absence of these unpaid services, the state would have spent much more on public provisioning. Unpaid work also fills gaps in infrastructure. For example, unpaid work includes fetching drinking water, sometimes from long distances; unpaid work provides fuel wood again from distant places when necessary, and ensures access to often distant basic services, such as health services. In short, unpaid work subsidizes government by provisioning to households.

Similarly, households also subsidize the market in the business sector. Unpaid work lowers the cost of labor at the macro level. The private sector has to pay much less than what it would have paid to maintain the same standard of living of workers (i.e., the wear and tear on workers, or labor depreciation, is taken care of by unpaid household services). This raises profits at the macro level, leading to an increase in the amount of capital accumulated and in economic growth.

However, because of this engagement in unpaid work, the work participation rates of unpaid workers (women) decline in the labor market, reducing the total workforce/labor force in the economy (Economic Commission for Latin America and the Caribbean 2007, Hirway 2008). A significant number of women are not participating in the labor market because of their domestic duties. As this is not an optimal use of labor in the economy, it is a loss to the macroeconomy (IMF 2013).

\section{Unequal Distribution of Unpaid Work across Gender and Macroeconomic Losses}

In spite of constituting 50\% (or 48-49\%) of the population, women's contribution to the conventional macroeconomy is very small, both in terms of their labor market participation rate and in terms of their share in high productivity sectors. Women contribute much less than their potential to the economy (IMF 2013). 
The unequal burden of unpaid work on women divides the labor market on gender lines (IMF 2013, Hirway 2008, Esquivel 2008). The burden of unpaid work, along with the social norms and traditions attached to it, results in lower accumulation of human capital (health, education, skills, etc.) by women, which in turn, constrains women's performance in the labor market.

When most women enter the labor market, they enter with a burden of responsibilities of unpaid work on their shoulders, which tends to deny them a level playing field at the outset. Women's lower level of education/skills, along with their lower mobility, results in their lower participation in the labor market, as well as overcrowding in low-productivity occupations, lower wages, and higher unemployment rates. The segregation and discrimination against women tends to reduce their prospects in the labor market. Female entrepreneurs also tend to be constrained due to their lower access to resources, to credit, and to technology (IMF 2013). In short, the sex-based division of labor at home and in the market does not allow an economy to tap the full potential of its labor force. The International Monetary Fund (IMF) estimates that the GDP of a country can increase considerably if the full potential of the female labor force is tapped.

\section{Neo-liberal Policies and Unpaid Work}

It has been argued that neo-liberal policies, through their impact on unpaid work, have an adverse impact on the economy (Elson 2008). Nancy Folbre argues that neo-liberal policies have offloaded the cost of these economic policies to unpaid workers (Folbre and Yoon 2008). Diane Elson also argues that the success of the neo-liberal policies in increasing economic growth is usually achieved at the cost of women, and this in turn incurs macroeconomic losses. For example, trade liberalization expands global markets for domestic products and raises the rate of economic growth. However, it also results in the restructuring of production (for flexibility) and the restructuring of labor (for flexibility and for reducing the cost of labor). As women with the burden of unpaid work fit well in this flexibility system, they end up taking work (usually at the low end of the value chain) which is of poor quality, i.e., with low wages, poor or no social protection, low employment status, and with poor terms of employment in general. This tends to increase the total burden of work, resulting in greater time stress. This is not only a loss of well-being for part of the workforce (usually women) but it is also a depletion 
of human capital (of women) and a sub-optimal use of the labor force in the economy.

Ultimately this reduces the potential gains to the economy in the long run.

Similarly, when public expenditure is reduced to meet fiscal deficit targets (as is done frequently by governments for macroeconomic stability), it tends to reduce the expenditure on health, education, and public services. This in turn tends to increase the burden of unpaid work on women. As privatization of these services makes them expensive, these services are brought into households as a part of their coping strategy, reducing their well-being and human capital / productivity on the one hand, and care deficiency in the economy on the other hand. These negative consequences, however, go unnoticed due to the lack of data, and are not addressed by suitable policies. In other words, a partial view of the economy and partial policymaking result in several distortions at the macroeconomic level.

\section{Integrating Unpaid Work in the Macroeconomy}

It can be argued now that non-SNA work is a part and parcel of the macroeconomy. SNA work and non-SNA work are closely linked with each other, and together they form the macroeconomy. These categories of work are not in separate watertight compartments. Activities move from SNA to non-SNA status and vice versa- not only for households with different characteristics, ${ }^{13}$ but also under different macroeconomic conditions. For example, during a slump period when employment and income are falling, households tend to increase their unpaid work as a coping strategy by bringing some paid activities into the household; and conversely during a boom when employment and incomes are rising, households tend to reduce their unpaid work by taking this work to the market, as they can now afford to buy market services. This anti-cyclical behavior of unpaid work is a good indicator of the macroeconomic interactions of both the categories of work. Given the limited capacity of women to give care, this perhaps implies that the economy tends to suffer from a care crisis during a slump, unless the government intervenes in a big way. It also implies that there is a continuum between paid (SNA) and unpaid (non-SNA) work, and that unpaid work needs to be treated as work in the economy and unpaid workers need to be covered under macroeconomic policies and under labor

\footnotetext{
${ }^{13}$ The size and nature of unpaid work at the household level tend to depend on household income; structure, size and composition of households; presence of elderly, sick or disabled persons in the household; prevailing social norms, etc.
} 
and employment policies. An important question in this context, therefore, is how to integrate unpaid work with the macroeconomy and macroeconomic policies.

\section{The Triple "R" Approach}

The triple " $\mathrm{R}$ " approach for integrating unpaid work with macroeconomic policies was first recommended by Diane Elson (2008). It is now a well-accepted approach. This approach attempts to integrate unpaid work into the mainstream economy by reducing it and by reorganizing it between paid and unpaid work. Such integration is expected to improve the efficiency of the total workforce on the one hand and reap some macroeconomic gains on the other hand.

The first " $R$ " refers to the "recognition" of unpaid work, viz. giving visibility to this work in national statistical system. This is to be achieved mainly through conducting regular time use surveys that collect detailed and comprehensive information on all human activities, including unpaid activities. Giving visibility implies: (a) providing information on the participation of women and men, as well as boys and girls in different activities, including unpaid activities, along with the time spent by them on these activities; (b) providing information on the technology used in the different unpaid (and other) activities, including the drudgery involved and time stress experienced by workers; (c) estimating the determinants of the nature and size of unpaid work in terms of socioeconomic characters of the household and individuals; and (d) showing how the sum total of care is shared by the government, the market, civil society organizations, and within the household. All this information helps in designing interventions to reduce and reorganize this work.

The second " $R$ " refers to reduction in unpaid work in order to reduce the drudgery part of the work as well as the time stress of unpaid workers. This can be done in multiple ways: (1) by improving the technology of some work to reduce drudgery and to improve the productivity of unpaid work (e.g., providing fuel-efficient stoves for cooking in place of primitive stoves using fuel wood), (2) by providing infrastructural support to reduce drudgery (e.g., providing water supply at the door step), and (3) by making basic services accessible through improving connectivity (e.g., good roads and transportation services) or by setting up such services at convenient locations. These steps will release women from the burden of unpaid work, and reduce their time stress to enjoy leisure or to participate in productive work. In the case of 
children performing this work, these steps will release children so they can fully participate in education.

The third " $R$ " refers to the redistribution of unpaid work within the household and within the four institutions (care diamond institutions). The redistribution of unpaid work within the household requires changes in the prevailing patriarchal norms and customs. This kind of redistribution is essential primarily for providing a level playing field to women in the economy, and particularly in the labor market for achieving an optimally efficient allocation of the labor force. Even if outside institutions share unpaid work, some unpaid work will always remain within the household. ${ }^{14}$ Government may consider providing incentives to encourage the sharing of unpaid work by men. ${ }^{15}$

The redistribution of unpaid care between the other caregiving institutions calls for shifting some unpaid work to the mainstream economy - to the market, to the public sector, or to the voluntary sector (paid /unpaid). The unpaid work that can be shifted to the mainstream economy is frequently termed as "hidden vacancies" (Antonopoulos and Fontana 2006), i.e., the vacancies which should be in the mainstream economy but are hidden, as these are inadequately filled in by unpaid work. The type of unpaid work that can be shifted to the mainstream economy could be: (1) child care - taking care of children when mothers are working or not working, i.e., taking care of infants and children, feeding them and taking care of their other needs, and (2) taking care of the disabled, the chronically sick, other sick, elderly persons, etc. This care, when given by households as unpaid care, is frequently inadequate, either in terms of the time spent on it, or in terms of its quality, regularity, and reliability. However, if new jobs are created in the mainstream economy to provide this care, the state can ensure the delivery of professional care with regularity on the one hand and unpaid workers can be released from the time stress of this burden on the other hand. The women released from this work may also participate in productive work in the mainstream economy, leading to an optimal use of the labor force. It should be reiterated that not all unpaid care/work can be or should be transferred to the mainstream economy.

This reallocation of care resulting in the reorganization of the labor force (paid + unpaid) has to be a part of a national labor policy for multiple reasons: it tends to provide a level playing

\footnotetext{
${ }^{14}$ In the words of Nancy Folbre, this work is what keeps family together and nurtures social values

${ }^{15}$ Government may provide paternity leave, special incentives if men share child care, etc. That is, some steps that encourage men to share unpaid work to reduce the unpaid work of women.
} 
field to women workers in the labor market — for gender justice, as well as for raising workforce participation rates (WPR) of women; it creates new paid employment opportunities in the mainstream economy; it ensures professional care (and solves a major problem of care deficiency seen at present) for those who need it; and it tends to optimize the use of the labor force in the economy.

Such an approach may raise public expenditure considerably (when attempts are being made to contain it under the neo-liberal policy framework), and may also create inflationary pressure in the economy by adding to the purchasing power in the economy. However, it can be argued: (1) the generation of mainstream employment, as well as ensuring professional child care, have significant multiplier impacts at the macro level ${ }^{16}$ (Antonopoulos et al. 2014), and (2) the financial space of the budget can be increased by following the principle of "maximum available resources" ${ }^{\prime 17}$ (Balakrishnan et al. 2011). The returns from the reorganization of labor will certainly outweigh the costs.

\section{Valuation of Unpaid Work into Satellite Accounts}

The valuation of unpaid work in money terms is another approach of integrating unpaid work with the mainstream economy. Valuation essentially describes unpaid work in monetary unitsthe same unit in which GDP is valued. This makes it possible to give visibility to this work in terms of its share of the total well-being of the economy. Valuation is also expected to help in estimating the total GDP for the expanded macroeconomy. To put it differently, if the economy consists of the three sectors (i.e., the household, the market, and the government), valuation helps in estimating their respective contributions in a common unit.

The valuation of unpaid work is a subject of debate in the literature. On the one hand, there are scholars who argue that "care" is much more than "labor" and cannot be commoditized

\footnotetext{
${ }^{16}$ The SAM-based analysis by the authors shows that this positive multiplier effect is in terms of employment, income, and output.

${ }^{17}$ The resources with the government depend on (1) expenditure, aid, and taxation; (2) borrowings and running deficits; (3) monetary space that is determined by the Central Bank's policies that impact rate of interest, exchange rates, foreign exchange reserves, etc. If the monetary and fiscal policies are used as major tools to reach full employment, it is possible to get out of the narrow scope and raise finances for developmental goals (Balakrishnan et al. 2011). Some of the other means of raising the national finances will be: reduction in defense expenditure, eliminating bad subsidies (i.e. crony capitalism) and tracing black money - all the three sources can generate huge funds; giving priority to developmental goals and changing expenditure accordingly. Gender responsive budgeting can play a big role here, raising taxes on wealth and incomes, borrowings or deficit financing could also raise the resources to a great extent, and accessing funds from donor agencies could also be a good source (Hirway 2014a).
} 
in money terms. It is also argued that it is not easy to get the right prices of some of the activities performed as unpaid work — such as telling bedtime stories to children (Folbre 2001). In fact, valuation implies comparing oranges and apples, the two sets of work performed in totally different environments, i.e., the competitive environment of the market and the work in the home, where profit is not a motive. It is also argued that valuation of unpaid work will inflate incomes, particularly of the poor who spend a good amount of time on unpaid work. This may give a false signal about the levels of the standard of living of the poor and of the overall standard of living in poor countries.

On the other hand, some scholars argue that the valuation of unpaid work in money terms gives visibility to the contribution of unpaid work as compared to that of national GDP. This value justifies the claim of unpaid workers on the public exchequer, as it allows them to demand funds for improving their technology and working conditions and even pension benefits. Valuation also gives estimates of total well-being of the economy in terms of a wider estimate of GDP, and thereby gives full visibility to women's unpaid work (Collas-Monsod 2010). Finally, it is also argued that comparing the GDP estimates of different countries at present (without adding the value of unpaid work) is like comparing apples and oranges, as some countries exclude domestic services (when unpaid) while the other countries (richer countries) include the same services in national income as they are priced in the market (Sharma 2012). In order to make the GDPs of different countries comparable, it is necessary to merge the conventional GDP with the value of unpaid work, if not today at a later stage.

The arguments in favor of valuation appear to be stronger from a macroeconomic point of view. Several global organizations and global summits have recommended the valuation of unpaid work (UN 1993 and 2008, UNDP 1995, ILO 2013, Beijing Platform for Action 1995). The argument that valuation will inflate the incomes of the poor and inflate the national GDP does not seem to be valid on the grounds that (1) the GDPs of different countries will be comparable only when all countries add the value of the unpaid work in the expanded GDP, and (2) a major objective of compiling national income accounts is also to study the structure of an economy - the higher share of GDP from unpaid work will definitely be considered a problem for poor countries.

However, one has to be very careful about the methodology used for valuing unpaid work. The most common approach to the valuation of unpaid work at present appears to be the input method, under which the labor component of the unpaid work is valued by different 
market wage rates (Fukami 2000, Hitoshi 2000, Nath 2003, Budlender and Brathaug 2000, Eun and Ryu 2012), such as housekeeper's wages, specialized wages, or opportunity costs. ${ }^{18}$ Though the debate on the wage rate is ongoing, it is now realized that the input method is inadequate, as it pays no attention to the productivity of unpaid time. ${ }^{19}$ The other approach recommended is the output method, in which the unpaid time use is converted into outputs (for example, number of meals produced, number of clothes washed, rooms cleaned, etc.), and the value is computed using the relevant market prices. Though the output approach appears to be more logical, it is found to be clumsy, as it is not always easy to convert all unpaid services into products.

The accepted method at present is to compile systematic satellite accounts of household unpaid services. Satellite accounts generally address the need to expand the analytical capacity of national accounting for selected areas of social concern in a flexible manner, without overburdening or disrupting the central system (UN 1993, 2008). The satellite account of unpaid work is an extension of the national accounts system beyond its conventional limits. It experiments with new concepts and methods and provides a wider view of the national income accounts. Once the methodology of these accounts finalized and firmed up, these accounts are expected to be merged with the main accounts.

Though several scholars have contributed to building the methodology for computing the satellite accounts of unpaid services, so far no agreement has been reached about a global methodology (Eurostat 2013; Hamunen et al. 2012; Holloway et al. 2002; Harvey and Mukhopadhyay 1996; Ironmonger and Soupourmas 2009). As a result, the task of valuation can be considered a "work in progress." In short, the valuation of unpaid work in money terms has some advantages in terms of integrating unpaid work with the mainstream economy. The task of integrating unpaid work with the mainstream economy by compiling satellite accounts is still a pending task.

\footnotetext{
${ }^{18}$ The wage rates used in computing value of unpaid time are (1) housekeeper's wages; (2) specialized wage rates for example, a commercial cook's wage rate for cooking time, a washer man's wage rates for washing time, etc.; and (3) opportunity cost where the wage rate is determined based on the wage rate the unpaid worker is likely to get based on her/his education/skills and other formal expertise. It has been observed that the housekeeper's wage rate gives the lowest value of the unpaid work, and the opportunity cost gives the highest value of unpaid work.

${ }^{19}$ However, as time use is stretchable, in the sense that the time spent on an activity depends on the available time (a housewife may spend two or more hours on cooking while a working woman may spend less than one hour), and on the technology (cooking with a primitive stove may need more time than cooking on a cooking rang), it does not reflect the productivity of time; and therefore the input method is not acceptable for valuation of non-SNA work.
} 
Though valuation is essential, there is also a need to go beyond valuation. This is because valuation does not fully integrate unpaid work in policymaking, as it keeps unpaid work separate from paid work. It shows the importance of unpaid work in terms of its contribution to overall well-being; however, it does not guide how this inferior and lagging sector of the unpaid economy can be integrated with the mainstream economy in a manner that its productivity and working conditions can be improved, or how it can be brought into mainstream policymaking. Valuation also does not show how this work can be redistributed. There is a need to develop an approach that goes beyond valuation to integrate unpaid work in macroeconomic policies so as to treat unpaid work as a component of the macroeconomy.

\section{Integrating Unpaid Work in Designing and Monitoring Macroeconomic Policies}

One major macroeconomic question that needs to be addressed for this integration to occur is to understand conceptually and empirically the dynamics of the linkage between paid and unpaid work. Some of the important theoretical questions that must be answered in order to understand the extended macroeconomies that include both paid and unpaid work are: What are the determinants of the nature and scope of unpaid work? How are they linked with the macroeconomy? And, how do the dynamics of this linkage change over time? As Luisella Goldschmidt-Clermont put it, sound theoretical work is needed to understand the linkages between paid and unpaid work to get a clear view of the dynamics of the expanded macroeconomy (Goldschmidt-Clermont 1989). The IMF also has emphasized acquiring a sound understanding of the linkages between paid and unpaid work. Somehow, not much work is done in this field.

At the empirical level, several approaches have been recommended by different scholars. One approach frequently recommended by scholars to address this integration is to analyze, conceptually and empirically, the impact of macroeconomic policies on paid and unpaid work. The IMF has also incorporated in its future plans an analysis of the impact of macroeconomic policies on unpaid work and gender inequalities (IMF 2013). "Similarly, ILO also recommends analysis of unpaid work and labor market participation of women and its macroeconomic effects as part of the Centenary Initiatives on Women at Work" (ILO 2014).

The impact of macroeconomic policies on paid work is usually analyzed by policymakers; however, the impact on unpaid work is excluded from both analysis and policymaking. Several studies in this area have shown that macroeconomic policies or sectorial 
policies have different impacts on paid and unpaid work. For example, the austerity policies used to address a global crisis tend to reduce social sector expenditure, which raises the burden of unpaid work on women, reducing women's well-being, as well as productivity. Trade liberalization policy, which promotes economic growth, is observed to be resulting in the "flexibility" of labor, and ultimately ends up promoting home-based production, usually by women. This raises the burden of paid and unpaid work on these workers, and frequently increases children's work time (both paid and unpaid). Consequently, on the one hand, women experience time stress and the depletion of their energy (and productivity), while on the other hand, children suffer in multiple ways, such as loss of childhood, sub-optimal growth, and care deficiency. Several other studies have been conducted by researchers in the context of global crises, austerity policies, trade policies, etc., and have produced similar results (Antonopoulos 2014). ${ }^{20}$ An important implication of the above is that policymakers tend to go very wrong in designing and monitoring macroeconomic policies if unpaid work is excluded from the policy analysis.

\section{Integration of Unpaid Work with Analysis and Policymaking in the Labor Market}

As seen above, the inferior status of women workers in the labor market cannot be analyzed satisfactorily without studying the constraints of their unpaid work. This is because the nature of their unpaid work will have a significant influence on their participation and the time spent on labor market activities. It will also influence their selection of work, their mobility, and other terms of employment. It is necessary, therefore, to incorporate unpaid work in understanding the functioning of labor markets, studying gender inequalities in the labor market, analyzing employment/unemployment-related issues, and in designing policies in this field.

In order to optimize the use of the total labor force (paid and unpaid) in the economy, it is important to see that the sex-based division of labor at home and in the labor market is corrected so as to provide a level playing field for all workers. As seen earlier, unpaid workers constitute the lagging segment of the labor force due to its built-in weakness, with the result that the full potential of the labor force is not tapped. It is important, therefore, to reduce and minimize the number of workers in this segment by reducing this work (by improving

\footnotetext{
${ }^{20}$ Please refer to Gender Perspective and Gender Impacts of the Global Economic Crisis, edited by Rania Antonopoulos, New York: Rutledge 2014.
} 
technology of this work and by facilitating this work through suitable infrastructure) and by transferring some work to the mainstream economy. This reorganization of the labor force between paid and unpaid work is necessary to optimize the use of the labor force in the economy. Again, it is also necessary to see that the division of labor between paid and unpaid work is based on the free choice of workers and not based on patriarchal values, as patriarchal values may restrict the entry of more efficient and more productive labor in the labor market.

In order to address the disadvantages of workers (who also have responsibility of managing domestic services at home) in the labor market, several policies have been formulated by governments (Hirway 2008): (1) providing flexi-timings to workers (part-time jobs, compressed work, staggered hours, etc.) to enable unpaid workers (mainly women) to manage unpaid and paid work together; (2) reducing the distance between the labor market and home (allowing working from home or home-based work); (3) financial assistance during child birth and paid leave for taking care of young infants and children (maternity benefits, extra leave, extended leave without pay, etc.); (4) financial incentives in terms of tax credits, bonuses, and allowances to parents, as well as the provision of social rights attached to caregiving, such as individual pension rights, or additional pension rights to compensate for time taken out of the labor market; (5) providing child care facilities, crèche services for young infants, midday meals in schools, etc.; (6) incentives to employers for employing women (particularly those women who re-enter the labor market); and (7) special training, retraining, and skill programs for women. These policies aim to help unpaid workers manage both paid and unpaid work. They are also expected to maintain and increase the WPR in the labor market to tap the full potential of women labor so as to maximize economic growth.

The IMF argues that this increase of the WPR of women is particularly important in the economies where the overall WPR is declining due to an ageing population. Again, women earning their own incomes in the labor market are expected to take better care of the health and education of their children. And this is also a macroeconomic gain (IMF 2013). It is important, however, to see that these supports and facilities address mothers and fathers equally. Otherwise, as is happening at present, all these policies will only reinforce the caregiving role of women, restricting their freedom in the labor market.

Another related point is that while designing employment policies for women, including skill formation policies, their impact on unpaid work is addressed by suitable provisions to enable equal opportunities for men and women in the labor market. For entrepreneurship 
development programs for example, it is necessary to address specific constraints faced by women to provide them with equal access to assets, credit, extension, technology, and other inputs. Similarly, it is important to emphasize that not factoring in this unpaid work will reduce the effectiveness of any kind of active labor market measures, such as skills development or employment of women, as women simply do not have the time to participate in such activities. If they do engage in these activities, it could well result in their children shouldering a larger burden of unpaid work.

\section{Concluding Observations}

It is clear that the implementation of these different approaches calls for a sound database (including regular production of quality time use statistics) and suitable analytical tools to analyze the data. Though this presentation does not deal with the data-related issues, it will be sufficient to state that a lot of work is needed in producing good quality data as well as in developing new analytical tools for using the data meaningfully. ${ }^{21}$ The ILO resolution in the $19^{\text {th }}$ ICLS is a good beginning in this direction.

In conclusion, the time has come for economic analysis and policy, including macroeconomics to take a wider view of the economy. Without incorporating unpaid work, it will remain partial and wrong. The time has also come for labor economics to incorporate unpaid work into the analysis of labor and employment for formulating realistic and efficient labor and employment policies.

\footnotetext{
${ }^{21}$ Hirway Indira (2014b), The Future of Time Use Research, presentation in the plenary Panel at the $36^{\text {th }}$ Annual Conference of International Association for Time Use Research in Turku, Finland.
} 


\section{References}

Antonopoulos, R. (2009) “The Unpaid Care Work-Paid Work Connection.” International Labour Office, Policy Integration and Statistics Department-Geneva: ILO. Working Paper No. 86.

(2014) Gender Perspectives and Gender Impacts of the Global Economic Crisis. New York: Routledege

Antonopoulos, R. and M. Fontana (2006) "Hidden Vacancies." Paper presentation at Levy Economics Institute conference Employment Guarantee Policies: Theory and Practice. The Levy Economics Institute of Bard College, Oct. 13-15. Annandale-on-Hudson, New York.

Antonopoulos, R. and I. Hirway (2010) "Unpaid Work and the Economy: Gender, Time Use and Poverty." In R. Antonopoulos and I. Hirway, eds. Unpaid Work and the Economy: Gender, Time Use and Poverty in the Global South, UK: Palgrave Macmillan.

Antonopoulos, R., T. Masterson, and A. Zacharias (2012) The Interlocking of Time and Income Deficits: Revisiting Poverty Measurement, Informing Policy Responses. Research Project Report. Annandale-on-Hudson, NY: Levy Economics Institute of Bard College. December. Part of the "Undoing Knots, Innovating for Change" series, issued by the UNDP Regional Centre for Latin America and the Caribbean through its Gender Practice Area.

Antonopoulos, R., T. Masterson, and A. Zacharias (2014) "Investing in Care in the Midst of Crisis: A Strategy for Effective and Equitable Job Creation in USA.” In Antonopoulos, R., ed. Gender Perspectives and Gender Impacts of the Global Economic Crisis. New York: Routledege.

Balakrishnan, R., D. Elson, J. Heintz, and N. Lusiani (2011) "Maximum Available Resources and Human Rights." Center for Women's Global Leadership, Rutgers University, New Jersey, USA.

Bardasi, E. and Q. Wodon (2006) "Measuring Time Poverty and Analyzing its Determinants: Concepts and Application to Guinea." In C. M. Blackden and Q. Wodon, eds. Gender, Time Use, and Poverty in Sub-Saharan Africa. International Bank for Reconstruction and Development, World Bank Working Paper No. 73.

Beijing Platform for Action (1995) Fourth World Conference on Women-Action for Equality, Development and Peace. September.

Blackden, C. M. and Q. Wodon (2006), "Gender, Time Use, and Poverty in Sub-Saharan Africa." World Bank Working Paper No. 73.

Budlender, D. (2010) What do Time Use Studies Tell Us about Unpaid Care Work? Evidence from Seven Countries. United Nations Research Institute for Social Development, Geneva. 
Budlender, D. and A. L. Brathaug (2000) "Calculating the Value of Unpaid Labour in South Africa." National Statistics Offices, South Africa.

Charmes, J. (2005) "A Review of Empirical Evidence on Time Use in Africa from UNSponsored Surveys." In C. M. Blackden and Q. Wodon, eds. Gender, Time Use, and Poverty in Sub-Saharan Africa. International Bank for Reconstruction and Development, World Bank Working Paper No. 73.

Collas-Monsod, S. (2010) "Removing the Cloak of Invisibility: Integrating Unpaid Household Services in National Economic Accounts - the Philippines Experience." In R. Antonopoulos and I. Hirway, eds. Unpaid Work and the Economy: Gender, Time Use and Poverty, pp. 230-51, New York: Palgrave Macmillan.

Economic Commission for Latin America and the Caribbean (ECLAC) (2007) Measuring Unpaid Work. Tenth session of the Regional Conference on Women in Latin America and the Caribbean. Quito, Ecuador.

Elson, D. (2008) “The Three R's of Unpaid Work: Recognition, Reduction and Redistribution.” Paper presented at the Expert Group Meeting on Unpaid Work, Economic Development and Human Well-Being, UNDP, New York, November 2008.

Esquivel, V. (2008) “A 'Macro' View on Equal Sharing of Responsibilities between Women and Men." Expert Group Meeting on Equal Sharing of Responsibilities between Women and Men, including Caregiving in the Context of HIV/AIDS. 53rd Meeting of the Commission for the Status of Women (CSW), United Nations Division for the Advancement of Women (DAW), New York.

Eun, K. and S. Ryu (2012) "Compiling Satellite Accounts for Korea." Paper presented at the International Conference Towards Harmonization of Time Use Surveys at the Global Level With Special Reference to Ministry of Statistics and Programme Implementation, Government of India, and Centre For Development Alternatives, New Delhi India.

Folbre N. (2001) The Invisible Heart: Economics and Family Values. New York: New Press.

Folbre N. and J. Yoon (2008) "Economic Development and Time Devoted to Direct Unpaid Care Activities: An Analysis of the Harmonized European Time Use Survey (HETUS)." Paper commissioned for the United Nations Research Institute for Social Development, Geneva, 2008.

Fukami M. (2000) "Monetary Valuation of Unpaid Work in 1996 in Japan." Paper presented at the International Seminar on Time Use Studies, December 7-9, 1999. Ministry of Statistics and Programme Implementation, Government of India, New Delhi.

Goldschmidt-Clermont, L. (1987) Economic Evaluations of Unpaid Household Work: Africa, Asia, Latin America and Oceania. Women, Work and Development Series no. 14. Geneva: ILO.

(1989) Unpaid Work in the Household: A Review of Economic Evaluation Methods. Women, Work and Development Series no. 1. Geneva: ILO. 
Hamunen, E., J. Varjonen, and K. Soinne (2012) "Satellite Accounts on Household Production: Eurostat Methodology and Experiences to Apply It." Paper prepared for the $32^{\text {nd }}$ General Conference of the International Association for Research in Income and Wealth, August 5-11, Boston USA.

Harvey, A. and M. E. Taylor (2000) "Designing Household Survey Questionnaires for Developing Countries: Lessons from Fifteen years of Living Standard Measurement Studies." The World Bank, Washington, D.C.

Hirway I. (2005) “Integrating Unpaid Work into Development Policy.” Paper presented at the Conference on Unpaid Work and Economy: Gender, Poverty and Millennium Development Goals, Levy Economics Institute, New York.

(2008) "Equal Sharing of Responsibilities between Men and Women: Some Issues with Reference to Labour and Employment." Paper prepared for and presented at the Expert Group Meeting on Equal Sharing of Responsibilities between Women and Men, including Caregiving in the Context of HIV/AIDS. 53rd Meeting of the Commission for the Status of Women (CSW), United Nations Division for the Advancement of Women (DAW), New York.

(2010) "Understanding Poverty: Insights Emerging from the Time Use of the Poor." In R. Antonopoulos and I. Hirway, eds. Unpaid Work and the Economy: Gender, Time Use and Poverty in the Global South, UK: Palgrave.

(2014a) "Has India Learned any Lessons from the Global Crisis? The Case of a Less Well-known but Most Globalized Industry from a Gender Perspective." In Antonopoulos, R., ed. Gender Perspectives and Gender Impacts of the Global Economic Crisis. New York: Rutledge.

(2014b) The Future of Time Use Research, presentation in the plenary Panel at the $36^{\text {th }}$ Annual Conference of International Association for Time Use Research

Hirway, I. and S. Jose (2011) “Understanding Women's Work Using Time Use Statistics: The Case of India.” Feminist Economics, 17(4): 76-92.

Hitoshi, M. (2000) “Time Use Surveys in Japan.” Proceedings of the International Seminar on Time Use Studies, CSO, Ministry of Statistics and Programme Implementation, Government of India, New Delhi.

Holloway S., S. Short, and S. Tamplin (2002) “Household Satellite Account (Experimental) Methodology." Office of National Statistics, London.

International Labour Organization (2013) Global Employment Trends 2013: Recovering from a Second Jobs Dip. Geneva: ILO.

(2014) Centenary Initiatives on Women at Work. Panel event to mark International Women's Day. Geneva: ILO. 
International Monetary Fund (2013) Women, Work, and the Economy: Macroeconomic Gains from Gender Equity. IMF Staff Discussion Note, September, 2013, Washington, D.C., USA.

Ironmonger, D. and F. Soupourmas (2009) "Estimating Household Production Outputs with Time Use Episode Data. Electronic Journal of IATUR, 6(2): 240-268.

Nath, S. K. (2003) "Valuation of Unpaid Household Work and Community Services Using Time Use Statistics." Presented in proceedings of the National Seminar on Applications of Time Use Statistics, Central Statistical Organization, Government of India.

Rizvi, S. and S. Staab (2010) "Gender, Poverty and Inequality: The Role of Markets, States and Households.” In S. Chant, ed. The International Handbook on Gender and Poverty. Edward Elgar Publishing: Northampton, 2010.

Sharma, S. (2012) "Valuation of Unpaid Work." Presentation made at the International Training Programme on Analysis of Time Use Statistics, organized by MOSPI, Government of India, CFDA under the IATUR-IAFFE project, Noida.

United Nations (1993) System of National Accounts. Washington, D.C: Inter-Secretariat Working Group on National Accounts. (1995) Human Development Report 1995. Delhi: Oxford University Press. (2008) System of National Accounts. Washington, D.C: Inter-Secretariat Working Group on National Accounts.

(2013) Special Rapporteur on Extreme Poverty and Human Rights, United Nations General Assembly, $68^{\text {th }}$ Session, New York, USA. 